\title{
Giant cells in pigmented villo nodular synovitis express an osteoclast phenotype
}

\author{
S D Neale, R Kristelly, R Gundle, J M W Quinn, N A Athanasou
}

\begin{abstract}
Aim-To determine the cytochemical and functional phenotype of multinucleated giant cells in pigmented villo nodular synovitis (PVNS).

Methods-Giant cells isolated from a patient with PVNS of the knee were assessed for a number of markers used to distinguish osteoclasts from macrophages/ macrophage polykaryons: evidence of tartrate resistant acid phosphatase (TRAP) activity; expression of CD11b, CD14, CD51, and calcitonin receptors; and the ability of the giant cells to carry out lacunar resorption.

Results-Isolated giant cells expressed an osteoclast antigenic phenotype (positive for CD51, negative for CD11b and CD14) and were TRAP and calcitonin receptor positive. They also showed functional evidence of osteoclast differentiation, producing numerous lacunar bone resorption pits on bone slices in short term culture. Conclusions-The giant cells in this case of PVNS express all the phenotypical features of osteoclasts including the ability to carry out lacunar resorption. This may account for the bone destruction associated with this aggressive synovial lesion. (f Clin Pathol 1997;50:605-608)
\end{abstract}

Keywords: villo nodular synovitis; osteoclasts; bone resorption; synovial macrophage

Pigmented villonodular synovitis (PVNS) is a diffuse villous or nodular tumour-like synovial lesion that affects joints, tendons, and bursae. ${ }^{12}$ Histologically, PVNS is characterised by the proliferation of synovial lining cells and a heavy diffuse subintimal infiltrate of mononuclear cells, largely macrophages, among which are scattered multinucleated giant cells; both mononuclear and multinucleated cells may contain phagocytosed haemosiderin or lipid. It is not known whether this giant cell rich synovial proliferation is reactive or neoplastic in nature, but in about one third of cases PVNS behaves aggressively, causing para-articular osteolysis with the formation of multiple cysts in the bone. ${ }^{2}$ Ultrastructural studies of both the villous and nodular forms of PVNS have shown the presence of synovial type A macrophagelike cells and synovial type B fibroblast cells; the multinucleated cells show similar features to the type A mononuclear cells, suggesting that they are formed by fusion of type A cells.

Multinucleated giant cells similar to those seen in PVNS may be found in a wide variety of giant cell lesions of bone and extraskeletal soft tissues. The giant cells from these various lesions have all been shown to be capable of lacunar bone resorption, a characteristic feature of osteoclasts. In skeletal giant cell containing lesions, such as giant cell tumour of the bone and giant cell reparative granuloma of the jaw, the giant cells exhibit all the defining characteristics of the osteoclast phenotype. ${ }^{45}$ In contrast, it has been shown that the giant cells derived from extraskeletal giant cell lesions, such as breast carcinoma with giant cells, ${ }^{6}$ pilar tumour of the scalp, ${ }^{7}$ and giant cell tumour of the tendon sheath ${ }^{8}$ do not exhibit the antigenic phenotype of osteoclasts and are unresponsive to calcitonin. In this study we have analysed the phenotype of giant cells in a case of PVNS of the knee that was confined to the synovium; our aim has been, not only to discover whether these cells express the phenotypic characteristics of osteoclasts or macrophage polykaryons but also to determine whether this analysis may provide some clue as to the nature of this potentially osteolytic synovial lesion.

\section{Methods}

CLINICAL DETAILS

An 18 year old school girl of Nigerian and white parentage presented with a spontaneous haemarthrosis of the left knee. There was no other joint involvement. Magnetic resonance imaging showed the typical changes seen in PVNS, with thickened synovial fronds and abundant haemosiderin; there was no radiological evidence of bone involvement. A synovectomy was performed, at which time it was noted that there was no evidence of bone involvement or damage to the articular surface, ligaments, or menisci.

ISOLATION AND CULTURE OF SYNOVIAL CELLS

The synovial tissue was washed thoroughly in Hanks's balanced salt solution (HBSS) (Gibco, UK) then cut into small pieces $\left(\sim 1.0 \mathrm{~mm}^{3}\right)$. The synovial fragments were digested in RPMI containing $1 \mathrm{mg} / \mathrm{ml}$ collagenase type I (Sigma, UK) and $0.25 \%$ trypsin for 90 minutes at $37^{\circ} \mathrm{C}$. The suspension was filtered through a $70 \mu \mathrm{m}$ cell strainer (Falcon, UK) before being centrifuged at $680 \times g$ for 10 minutes. The cell pellet was resuspended in $5 \mathrm{ml}$ RPMI (Sigma), containing $10 \%$ fetal calf serum (Sigma) (RPMI/FCS). The cell suspension $\left(1 \times 10^{5}\right.$ cells per well) was then added to $16 \times 7 \mathrm{~mm}$ wells of a tissue culture plate containing human cortical bone slices and $6 \mathrm{~mm}$ glass coverslips. The cell suspension was allowed to settle on the 


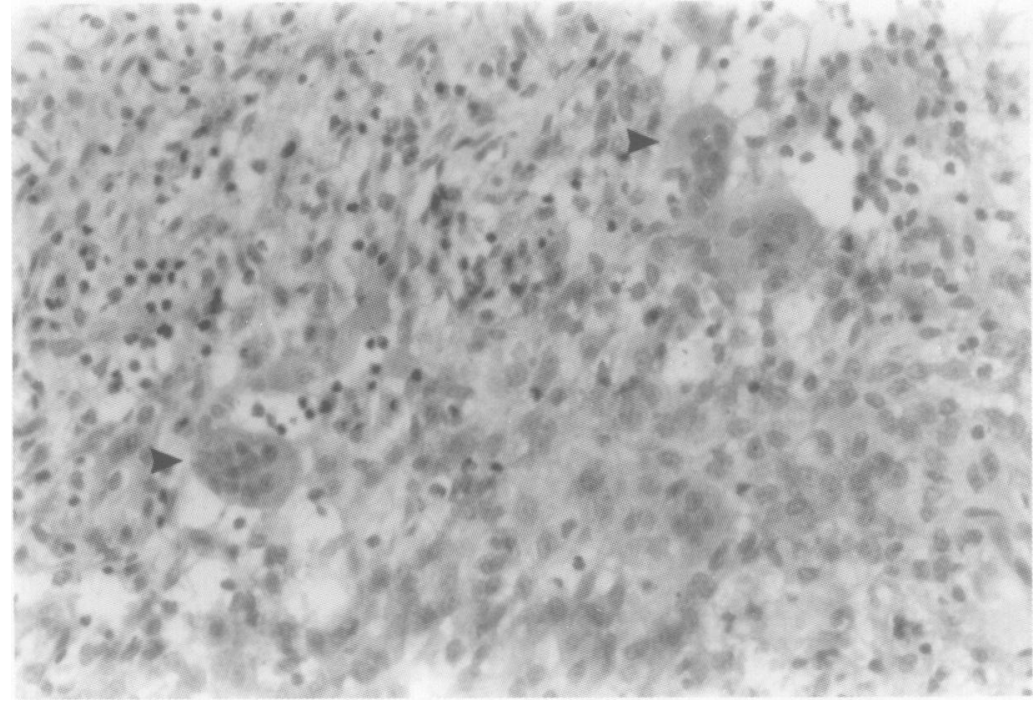

Figure 1 Histology of PVNS showing scattered multinucleated giant cells (some arrowed). (Haematoxylin and eosin, original magnification $\times 100$.)

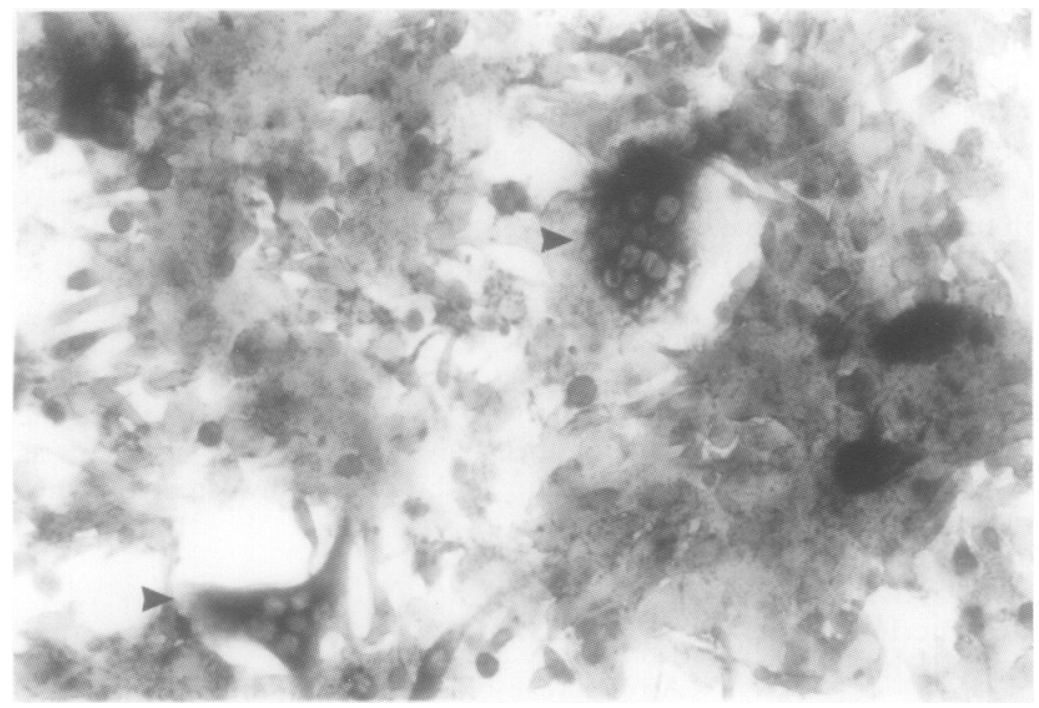

Figure 2 TRAP positive giant cells (some arrowed) in an imprint of PVNS tissue (original magnification $\times 250$ ).

coverslips and bone slices for one hour before being washed in HBSS and transferred to fresh wells containing RPMI/FCS. Half the cultures on bone slices were incubated for 24 hours and the remaining half for seven days.

CHARACTERISATION OF ISOLATED AND CULTURED CELLS BY CYTOCHEMISTRY AND

IMMUNOCYTOCHEMISTRY

Samples of synovial tissue were snap frozen in liquid nitrogen and stored at $-20^{\circ} \mathrm{C}$ for cryostat sectioning. In addition, imprints were made directly from small samples of pigmented synovial tissue. Glass coverslips containing 24 hour and seven day cultures were also fixed in cold acetone for immunocytochemistry.

The above preparations were stained cytochemically for tartrate resistant acid phosphatase (TRAP) an osteoclast associated enzyme, ${ }^{9}$ using a kit from Sigma, and immunocytochemically by an indirect immunoperoxidase technique with monoclonal antibodies 23C6 (a kind gift of Professor M Horton, London), MO1, and 10G 3.3 (derived from the Fourth International Workshop on Human Leucocyte Differentiation Antigens); these antibodies are directed, respectively, against CD51 (the vitronectin receptor) a highly osteoclast associated antigen, ${ }^{10}$ and CD11b and CD14, two monocyte/macrophage antigens known not to be expressed by osteoclasts. ${ }^{11}$

DETECTION OF CALCITONIN RECEPTORS ON

SYNOVIAL CELL CULTURES FROM PVNS

Cells isolated from synovial tissues, cultured on glass coverslips for three days, were also assessed for the presence of calcitonin receptors by autoradiography using ${ }^{125} \mathrm{I}$ labelled salmon calcitonin ligand binding as previously described. ${ }^{12}$ Cultures of synovial cells were incubated for one hour at $37^{\circ} \mathrm{C}$ in RPMI/FCS that contained $0.125 \mu \mathrm{Ci}^{125} \mathrm{I}$ calcitonin (Amersham International, Aylesbury, UK). After allowing labelled calcitonin to bind for two hours, the cells were washed with cold RPMI, fixed for 10 minutes in phosphate buffered $2 \%$ glutaraldehyde $/ 10 \%$ formalin solution, then air dried. Non-specific binding was assessed in the presence of an excess amount of unlabelled calcitonin ( $300 \mathrm{nM})$ which was added before the ${ }^{125} \mathrm{I}$ calcitonin. The coverslips were dipped in $\mathrm{K}-5$ photographic emulsion and processed for autoradiography.

FUNCTIONAL ASSESSMENT OF THE ABILITY OF CULTURED CELLS TO CARRY OUT LACUNAR BONE RESORPTION

Cells isolated from the PVNS synovium were settled on bone slices for 60 minutes, washed vigorously in HBSS then transferred to fresh wells containing RPMI/FCS in which they were incubated for periods of 24 hours and seven days. Two of the bone slices were fixed in glutaraldehyde, dehydrated in graded alcohols, and critical point dried before being sputtered with gold and examined in a Phillips SEM 505 scanning electron microscope. To assess more accurately the number of lacunar resorption pits produced by cells cultured on bone slices, the cells were removed from the bone surface by treating the bone slices for 15 minutes with a $0.25 \%$ trypsin solution, rinsing the bone slices vigorously in distilled water and immersing them in $0.25 \mathrm{M}$ ammonium hydroxide overnight. Bone slices were then washed in distilled water and dehydrated in graded alcohols before being air dried and sputtered with gold before examination in the scanning electron microscope.

\section{Results}

SYNOVIAL PATHOLOGY

Grossly, the synovial membrane and capsule were $\tan /$ brown in colour and showed focal areas of nodular thickening. Histologically, the typical features of PVNS were seen with villous hypertrophy and thickening of the synovial membrane, intimal hyperplasia, and a heavy subintimal macrophage and giant cell infiltrate associated with abundant haemosiderin deposition (fig 1); scattered lymphocytes and very occasional plasma cells were also noted. 


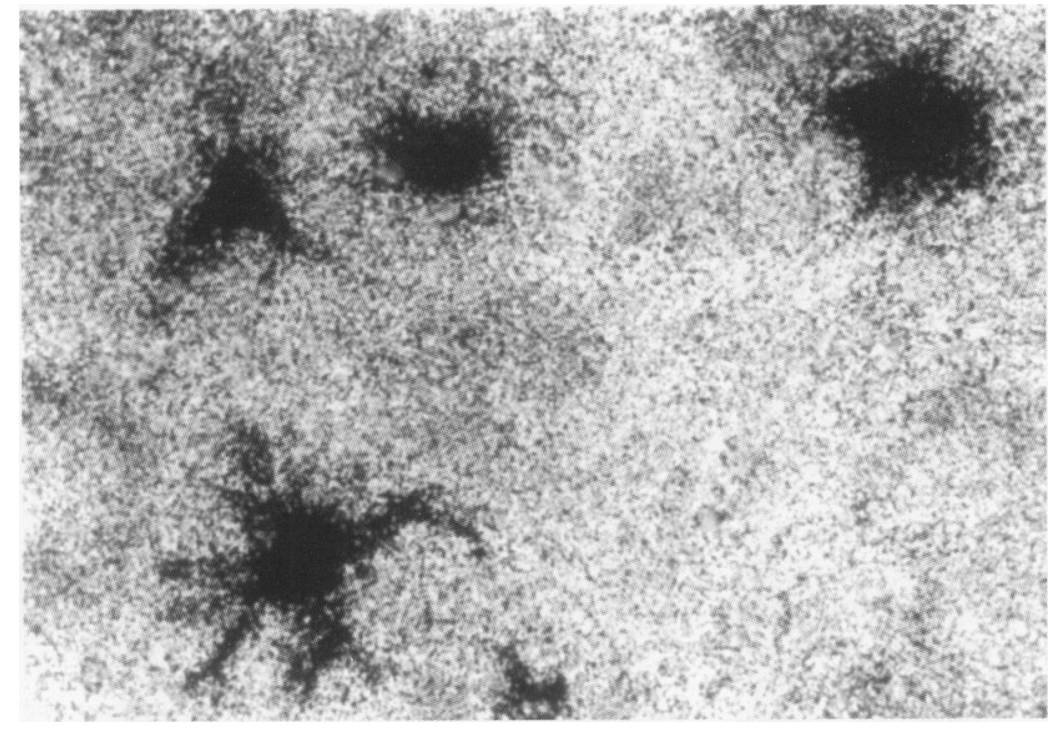

Figure 3 Culture of PVNS cells showing binding of ${ }^{125}$ I labelled calcitonin by autoradiography (original magnification $\times 250$ ).

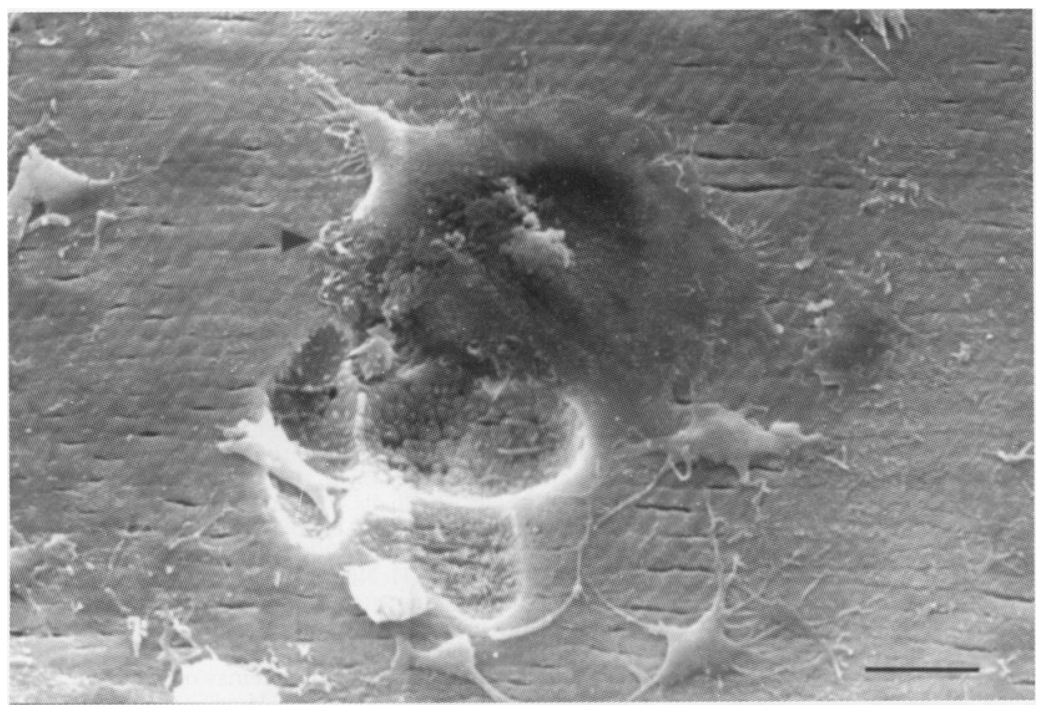

Figure 4 PVNS giant cell (arrowed) overlying a lacunar resorption pit on the bone surface (black bar $=10 \mu \mathrm{m})$.
In addition, cultured giant cells were found to contain numerous calcitonin receptors when assessed for their ability to bind ${ }^{125} \mathrm{I}$-labelled calcitonin by autoradiography (fig 3). A few giant cells were, however, found to be negative for calcitonin receptors.

In the scanning electron microscope bone resorption assay, there was functional evidence of osteoclast differentiation with several giant cells lying directly over or beside areas of lacunar resorption of the cortical bone surface (fig 4). Extensive lacunar resorption was seen on bone slices where cultured cells had been removed. All 16 bone slices on which cells had been cultured for 24 hours and seven days showed evidence of lacunar resorption. The average number of lacunar resorption pits seen after cells were cultured for 24 hours on the six bone slices on which cells had been removed was 43 (range 35-59), and on the same number of bone slices after seven days, 149 (range 124-173).

\section{Discussion}

PVNS is an enlarging, locally aggressive synovial tumour that not uncommonly causes erosion of bone contiguous with the joint synovium. It is characterised by the presence of numerous macrophages and giant cells. Our findings show that in this case of PVNS, where the pathology was confined to the synovium and there was no evidence of osteolysis, the giant cells expressed all the phenotypic characteristics of osteoclasts. Unlike macrophage polykaryons, PVNS giant cells strongly expressed TRAP, an osteoclast associated enzyme, and were strongly positive for the vitronectin receptor and negative for $C D 11 \mathrm{~b}$ and CD14..$^{9-11}$ The giant cells also expressed calcitonin receptors, ${ }^{12}$ as previously noted by Gravellese $e t a l{ }^{14}$ and were capable of extensive lacunar bone resorption.

The origin and nature of both the diffuse and localised forms of joint PVNS is controversial. It is not certain whether PVNS represents a true neoplasm of synovial tissue or an exuberant proliferative response of the synovium, possibly related to trauma or inflammation. ${ }^{2}$ Cytogenetic studies and flow cytometry have shown evidence of clonality in PVNS tissues, suggesting that PVNS may represent a true synovial neoplasm. ${ }^{15} 16$ A similar controversy surrounds the nature of giant cell tumours of the bone which have also been found to exhibit consistent chromosomal abnormalities. ${ }^{17}$ PVNS and giant cell tumour of the bone (as well as giant cell reparative granuloma of the jaw) are distinguished from other skeletal and extraskeletal giant cell lesions by the fact that the giant cells express the phenotype of osteoclasts rather than macrophage polykaryons. These three lesions also exhibit a similar pattern of osteolysis, behaving inherently as locally aggressive tumours, tumour growth or expansion being accompanied by bone destruction. On the basis that the giant cells are osteoclastic in nature, calcitonin administration has been used successfully to treat the enlargement of giant cell reparative vitronectin receptor.

Similarly, in cell cultures incubated on glass coverslips for 24 hours, giant cells were found to be positive for TRAP and the vitronectin receptor, and negative for CD11b and CD14. 
granulomas of the jaw, ${ }^{18}$ and potentially a similar approach could be used to control the osteolysis of PVNS.

It is now known that the human osteoclast precursor circulates in the monocyte fraction and that multinucleated cells exhibiting all the specific phenotypic characteristics of osteoclasts, including that of lacunar resorption, can be formed both from isolated cell preparations of the monocyte fraction of peripheral blood and tissue macrophages, including those derived from the synovial membrane. ${ }^{19} 20 \mathrm{~A}$ prominent feature of both skeletal and extraskeletal giant cell containing lesions from which lacunar bone resorbing giant cells have been isolated is the presence of a heavy macrophage infiltrate. Thus, lacunar bone resorption by giant cells found in a number of extraskeletal lesions may reflect the fact that these lesions contain not only numerous macrophages that are capable of fusing to form macrophage polykaryons but also a number that are primed and activated for osteoclast differentiation. This may be reflected in the fact that a variable number of the giant cells in these lesions express the antigenic phenotype of macrophage polykaryons rather than osteoclasts. $^{6-8}$ It could also account for the marked variation in the amount of lacunar resorption effected by giant cells isolated from different extraskeletal giant cell containing lesions; thus, in seven day cultures on bone slices, giant cells isolated from giant cell tumour of the tendon sheath, a lesion which closely resembles joint PVNS histologically, formed fewer than 10 resorption pits compared with over 100 in this present case of PVNS. This marked difference in lacunar resorption by giant cells isolated from the present case of PVNS and giant cell tumour of the tendon sheath, therefore, may be accounted for by a difference in the number of primed mononuclear phagocyte osteoclast precursors present in these two morphologically similar extraskeletal giant cell containing lesions.

We thank Mrs Margaret Pearce for typing the manuscript. RK was funded in part by the ERASMUS Programme.
1 Jaffe HL, Lichtenstein L, Sutro CJ. Pigmented villonodular synovitis: bursitis and tenosynovitis. Arch Pathol 1941;31:731-65.

2 Flandry R, Hughston JC. Current concepts review: pigmented villonodular synovitis [abstract]. $\mathcal{f}$ Bone foint pigmented villonod
Surg 1987;69:942.

3 Alguacil-Garcia A, Unni KK, Goellner JR. Giant cell tumour of tendon sheath and pigmented villonodular synovitis: an ultrastructural study. $\mathrm{Am} f \mathrm{Clin}$ Pathol 1978;69:6-17.

4 Joyner CJ, Quinn J, Triffitt JT, Athanasou NA. Phenotypic characterisation of mononuclear and multinucleated cells of giant cell tumour of bone. Bone and Mineral 1992;16:3743.

5 Flanagan AM, Chambers TJ. The multinucleate cells in giant cell granulomas of the jaw are osteoclasts. Cancer 1985;62:1 139-45.

6 Athanasou NA, Wells CA, Quinn J, Ferguson DJP, Heryet

A, McGee JO'D. The origin and nature of stromal A, McGee JO'D. The origin and nature of stromal
osteoclast-like multinucleated giant cells in breast carcinoma: implications for tumour osteolysis and macrophage biology. $B r \mathcal{F}$ Cancer 1989;59:491-8.

7 Athanasou NA, Quinn J. Bone resorption by macrophage polykaryons of a pilar tumour of the scalp. Cancer 1992;70: 469-75.

8 Athanasou NA, Quinn J Ferguson D, McGee JO'D. Bone resorption by macrophage polykaryons of a giant cell tumour of tendon sheath. Br $尹$ Cancer 1991;63:527-33.

9 Minkin C. Bone acid phosphatase: tartrate-resistant acid phosphatase as a marker of osteoclast function. Calcif Tissue Int 1982;34:285-90.

10 Horton MA, Lewis D, McNulty K, Pringle JAS, and Chambers TJ. Monoclonal antibodies to osteoclastomas (giant cell bone tumours): definition of osteoclast specific cellular antigens. Cancer Res 1985;45:5663-9.

11 Athanasou NA, Quinn J. Immunophenotypic differences between osteoclasts and macrophage polykaryons: immunohistological distinction and implications for osteoclast ontogeny and function. $f$ Clin Pathol 1990;43:997-1004.

12 Nicholson CG, Moseley JM, Sexton PM, Mendelsohn FAO. Abundant calcitonin receptors in isolated rat osteoclasts. $\mathcal{f}$ Clin Invest 1986;78:355-60.

13 Athanasou NA, Quinn JM, Horton MA, McGee JO'D. New Athanasou NA, Quinn JM, Horton MA, McGee JO'D. New
sites of cellular vitronectin receptor immunoreactivity sites of cellular vitronectin receptor immunoreactivity
detected with osteoclast-reacting monoclonal antibodies 13C2 and 23C6. Bone and Mineral 1990;8:7-22.

14 Gravellese EM, Darling JM, Gimcher LJ, Giowacki J, Want $\mathrm{J}-\mathrm{T}$, Harada Y, et al. Multinucleated cells in pigmented villonodular synovitis express an osteoclast phenotype [abstract]. Arthritis Rheum 1993;36(suppl):S190.

15 Ray RA, Morton CC, Lipinski KK, Carson JM, Fletcher JA. Cytogenetic evidence of clonality in a case of pigmented villonodular synovitis. Cancer 1991;67:121-5.

16 Bridge JA, Neff JR, Bhalla PS, Sanger WG, Murphy MD. Cytogenetics findings and biologic behaviour of giant cell tumours of bone. Cancer 1990;65:2697-703.

17 Choong PFN, Willen H, Nilbert M, Mertens F, Mandahl N, Carlen $\mathrm{B}$, et al. Pigmented villonodular synovitis: monoclonality and metastasis - a case for neoplastic origin? Acta Orthop Scand 1995;66:64-8.

18 Harris M. Central giant cell granulomas of the jaw regress with calcitonin therapy. Br f Oral Maxillofac Surg 1993;31: 89-94.

19 Fujikawa Y, Quinn JMW, Sabokbar A, McGee JO'D, Athanasou NA. The human mononuclear osteoclast precursor circulates in the monocyte fraction. Endocrinology 1996; 137:4058-61.

20 Fujikawa Y, Sabokbar A, Neale S, Athanasou NA. Human osteoclast formation and bone resorption by monocytes and synovial macrophages in rheumatoid arthritis. Ann Rheum Dis 1996;55:816-22. 